\title{
Heterogeneous Resources and the Financial Crisis Implications of Strategic Management Theory
}

Agarwal, Rajshree; Barney, Jay B.; Foss, Nicolai J.; Klein, Peter G.

Document Version

Final published version

Publication date:

2009

License

CC BY-NC-ND

Citation for published version (APA):

Agarwal, R., Barney, J. B., Foss, N. J., \& Klein, P. G. (2009). Heterogeneous Resources and the Financial Crisis: Implications of Strategic Management Theory. Center for Strategic Management and Globalization. SMG Working Paper No. 6/2009

Link to publication in CBS Research Portal

\section{General rights}

Copyright and moral rights for the publications made accessible in the public portal are retained by the authors and/or other copyright owners and it is a condition of accessing publications that users recognise and abide by the legal requirements associated with these rights.

Take down policy

If you believe that this document breaches copyright please contact us (research.lib@cbs.dk) providing details, and we will remove access to the work immediately and investigate your claim. 
Heterogeneous Resources and the Financial Crisis: Implications of Strategic Management Theory

\author{
Rajshree Agarwal \\ Jay B. Barney \\ Nicolai J. Foss \\ Peter G. Klein
}

SMG WP 6/2009

July 28, 2009 
SMG Working Paper No. 6/2009

July 28, 2009

ISBN: 978-87-91815-47-8

Center for Strategic Management and Globalization Copenhagen Business School

Porcelænshaven 24

2000 Frederiksberg

Denmark

www.cbs.dk/smg 


\title{
HETEROGENEOUS RESOURCES AND THE FINANCIAL CRISIS: IMPLICATIONS OF STRATEGIC MANAGEMENT THEORY
}

\author{
Rajshree Agarwal \\ University of Illinois at Urbana-Champaign \\ Jay B. Barney \\ The Ohio State University \\ Nicolai J. Foss \\ Copenhagen Business School and \\ Norwegian School of Economics and Business Administration \\ Peter G. Klein \\ University of Missouri
}

July 28, 2009

Strategic Organization, forthcoming

Corresponding author: Peter G. Klein, Division of Applied Social Sciences, University of Missouri, Columbia, MO USA 65211, +1 573882 7008, pklein@ missouri.edu. We thank the editors and participants at the 2009 Atlanta Competitive Advantage Conference for helpful comments and conversations. 


\section{HETEROGENEOUS RESOURCES AND THE FINANCIAL CRISIS: IMPLICATIONS OF STRATEGIC MANAGEMENT THEORY}

Macroeconomic theory assumes that factors of production in the economy are homogeneous and fungible. As a result, it may be ill-suited for developing policy responses to the recent financial crisis. Theories of strategic management and organization, with their emphasis on heterogeneously distributed resources and capabilities, may be better positioned. Examples of where macroeconomic theory may lead policies astray, and where theories of strategic management may be more appropriate, are provided. 


\section{INTRODUCTION}

The recent financial crisis and subsequent economic downturn are among the most important global economic events since the Great Depression of the 1930s (Elmendorf, 2009). In response to these events, macroeconomists have mustered their traditional theories to understand the causes of the crisis and, equally important, what might be done to help the economy recover more quickly. On op-ed pages, news talk shows, and-apparently - in the highest halls of governments world-wide, discussions about fiscal and monetary policy intervention have dominated much of the conversation about the crisis and what to do about it (Coy, 2009), and have led to talk of a return to the ideas of John Maynard Keynes (Fox, 2008). Economic policy decisions today, derived mostly from traditional macroeconomic theories, may have implications for the economy for decades to come (Elmendorf, 2009). Thus, the stakes are high, since the prosperity — and even survival — of billions of people around the world depend on a healthy and growing world economy.

In the midst of this obsession with macroeconomics, we would like to propose an alternative thesis: Macroeconomics, by itself, is not well equipped to deal with the current crisis and, in particular, a sole reliance on macroeconomic theory is likely to slow rather than accelerate economic recovery. The reason for this is that mainstream macroeconomic theories, whatever their stripe, all adopt the assumption that factors of production, firms, and industries in the economy are homogenous and fungible. This assumption makes it possible for macroeconomists to conclude that the economy, as a whole, can be managed by adjusting aggregate economy-wide indicators, for example, GDP, money supply, growth rates, and so forth. And yet, research in strategic management has consistently shown that the assumption that the economy is made up of homogeneous or fungible factors of production is incorrect.

It follows from this thesis that strategic management theory-with its emphasis on heterogeneously distributed and rather immobile and inelastic resources and capabilities - is positioned to make important contributions to the debate about the causes of the crisis and what 
might be done to help resolve it. This essay begins by focusing on a fundamental difference in the premises underlying dominant macroeconomic models and strategic management theory: heterogeneity of resources. This underlying assumption regarding resources leads to different fundamental understandings of how economic activity is organized and the roles of individuals, firms, and government in economic systems. We then discuss the implications of these different assumptions and understandings for economic policies derived from traditional macroeconomic theory and from strategic management theory.

\section{RESOURCE HOMOGENEITY IN MACROECONOMIC THEORY}

Mainstream macroeconomic models, given their focus on economy-wide phenomena (e.g., gross domestic or national product, employment, growth rates, etc.) tend to focus on aggregates, that is, industries, sectors, and entire economies (Mankiw, 2002). Economic models of industries and economies typically start with "representative firms," implying that all firms in an industry are alike (Carlton and Perloff, 2005). ${ }^{1}$ This mode of thinking is carried to the extreme particularly in modern mathematical macroeconomic models: all factors of production are assumed to be homogeneous within sectors. Thus, "labor" means homogeneous labor inputs; “capital" has the same interpretation. Nobel Laureate Robert Solow adopted the imagery of the "shmoo" from the comic Lil' Abner-shmoos are identical creatures shaped like bowling pins with legs - to capture this kind of homogeneity. This type of reasoning originated with David Ricardo (1817), who found it a useful simplification. And it can be. But sometimes economists' assumption of homogeneity can lead to trouble, as in the case of the causes of the current crisis and its proposed solutions, as we explain below.

In contrast, the idea that resources, firms, and industries are different from each other, that capital and labor are specialized for particular projects and activities, that people (human capital), etc. are distinct, is ubiquitous in the theory and practice of strategic management. The

\footnotetext{
${ }^{1}$ The simplifying assumption of the "representative firm," a firm picked at random from a population of identical firms goes back to the codification of microeconomic theory in the 1920s and 1930s (Foss, 1994).
} 
focus on heterogeneity of resources, including knowledge and managerial ability, in strategy and organization theory stems from heterogeneity being a critical determinant of competitive advantage (Barney, 1991). Superior profitability is seen as emerging from bundles of resources, with different resource bundles associated with different efficiencies. As a consequence, management scholars think of firms as bundles of heterogeneous resources, assets, and/or activities. These assets have different (economic) life expectancies. Such unique and specialized assets can also be intangible, such as worker-specific knowledge or firm-specific capabilities (Barney, 1986; Dierickx and Cool, 1989). These assets can be specific to certain firms, and "co-specialized" with other assets, such that they generate value only in certain combinations (Teece, 2009). Further, resource- and knowledge-based scholars often emphasize that heterogeneous assets usually do not give rise independently to competitive advantages. Rather, it is the interactions among these resources, their relations of specificity and co-specialization, that generate such advantages (e.g., Dierickx and Cool, 1989; Barney, 1991; Black and Boal, 1994; Teece, 2009). These interactions, coupled with path-dependent outcomes of past strategic investments in heterogeneous resources (Nelson and Winter, 1982) imply that heterogeneity, rather than homogeneity, is the hallmark characteristic of resources and firm organization of these resources. Models of the economy that are based on the assumption that capital is shmoo inherently cannot capture such heterogeneity and therefore fail to take into account the special problems of organization and allocation raised by the heterogeneity of capital.

Note that macroeconomics has not always neglected the above resource characteristics. In particular, the Austrian school of economics is notable for its long emphasis on the concept of heterogeneous capital which closely parallels the notion of heterogeneous resources. Early Austrian writers argued that capital has a time dimension as well as a value dimension. Carl Menger (1871), the founder of the Austrian school, characterized goods in terms of "orders": Goods of lowest order are those consumed directly. Tools and machines used to produce those consumption goods are of a higher order, and the capital goods used to produce the tools and machines are of an even higher order. Building on his theory that the value of all goods is determined by 
their ability to satisfy consumer wants (i.e., their marginal utility), Menger showed that the value of the higher-order goods is given or "imputed" by the value of the lower-order goods they produce. Moreover, because certain capital goods are themselves produced by other, higher-order capital goods, it follows that capital goods are not identical, at least by the time they are employed in the production process. The claim is not that there is no substitution among capital goods, but that the degree of substitution is limited; as Lachmann (1956) put it, capital goods are characterized by "multiple specificity." Some substitution is possible, but only at a cost. The overall picture of the economy painted in this theory-which in important ways is a macro-level mirror of resource-based and other strategic management theories - is one of a web of heterogeneous capital assets that stand in complex relations to each other, and do so for a reason. The resulting structure is one in which capital assets are deployed, combined, etc. in an attempt to direct production towards satisfying consumer preferences, contemporaneous as well as future ones. Nonetheless, the Austrian school is by no means a dominant paradigm in economic thought today, as evidenced by its absence from the leading macroeconomics texts (e.g. Mankiw, 2002) and its low profile in policy deliberations, either before or after the current economic crisis (for an exception, see Oppers, 2002).

\section{Micro Heterogeneity And Macro Phenomena}

That macroeconomic models assume factors of production in an economy are homogeneous is interesting, especially as compared to the typical assumption in strategic management theory and Austrian economics. But, does this assumption create problems for macroeconomics in either explaining the current crisis, or in deriving prescriptions for addressing it? We think so.

We start with the basic observation that economies do not make decisions, and neither do firms_-people make decisions (Felin and Foss, 2005). Certainly, macro-level factors influence individual decision making because economic activity is organized within firms and within particular institutional environments. Through history, the polar opposite political economic systems within which individuals make economic decisions are free-market or laissez faire capitalism- 
representing a separation of the economy and the state - and the central planning of socialism or communism, representing state ownership and organization of economic activity. An example of the latter is the erstwhile USSR; while the US has been heralded as a "free market" capitalist economy, it is better characterized as a mixed economy. More generally, the extent to which decision-making is governed by the market or government affects not only the degree of centralization of decision making, but also the economic consequences of the decision making.

Decentralized decision making is both required for, and results in, heterogeneity in resources. Schumpeter (1934), trained in the Austrian tradition, discussed how the gales of creative destruction in a capitalist economy enable growth through the independent decisions of entrepreneurs who introduced innovations that displaced existing products, services, and production modes. Hayek (1945) elaborated further on the fundamental role of heterogeneity in knowledge (as a source of subsequent heterogeneity in capital resources), helping explain why even a benevolent social planner, unmotivated by political or personal power considerations, could not allocate resources efficiently. No social planner can have access to the necessary tacit or specific knowledge, nor could she facilitate the experimentation required for trials and errors. In an entrepreneurial economy, by contrast, decentralized decisions made by co-creators of knowledge results not only in the heterogeneity of organization capabilities and performance, but also to the growth of industries, regions and economies (Agarwal, Audretsch and Sarkar, 2007).

To the extent that economic activity is organized within markets, and conducted by forprofit firms, these firms' resource-based strategies have important macro-level ramifications; specifically, processes of acquiring or developing, combining, and divesting resources fit into an overall structure of production that ultimately serves the preferences of consumers. The other side of the coin is that our knowledge of these firm-level processes forms an important microfoundation for our reasoning about what happens at the macro-level. For example, resourcebased theory in strategic management suggests that combining valuable resources isn't a simple process (as it would be, had resources been Solowian shmoo). For example, Makadok (2001) identifies the decision problem involved in the choice between "resource picking" or "resource 
development" and shows its complexity. Matsusaka (2001) argues that processes of mergers and divestments should be understood as experimental learning processes that must be undertaken exactly because it is not obvious ex ante what are the efficient combinations of assets. These micro-level processes are essentially entrepreneurial ones, because an important part of the entrepreneur's role is to arrange or organize heterogeneous resources. In Lachmann's (1956: 16) words, "We are living in a world of unexpected change; hence capital [resource] combinations . . . will be ever changing, will be dissolved and reformed. In this activity, we find the real function of the entrepreneur." As a result, the constraints, incentives, opportunities, etc. faced by entrepreneurs must ultimately enter as a crucial element in the understanding of macro phenomena.

\section{Heterogeneity And The Current ECONOMic Crisis}

\section{High Levels of Aggregation Are Potentially Misleading}

The U.S. bailout and stimulus programs begun by the Bush Administration in 2008 and continuing through the Obama Administration in 2009 represent a complex (and seemingly ad hoc) mixture of programs, some designed to rescue failing banks, to strengthen the financial sector overall, to help struggling homeowners, and to stimulate the economy as a whole. Similar, if smaller, programs have been planned and started elsewhere, notably in the European Union (Commission of the European Communities, 2008).

The US Emergency Economic Stabilization Act, which took effect in October 2008, authorized the Treasury to spend upwards of $\$ 700$ billion to purchase "troubled assets (such as mortgage-backed securities) from financial institutions, to make capital injections into banks, and to engage in other discretionary activities aimed particularly at the loan market. The European Union plan, proposed in November 2008, involves an "immediate budgetary impulse amounting to $€ 200$ bn" (Commission of the European Communities, 2008: 7).

The Obama Administration's American Recovery and Reinvestment Act, signed into law in February 2009, includes both "stimulus" and "infrastructure" spending. The latter is designed 
to target particular industries, regions, technologies, and business practices for government support and to provide incentives for particular kinds of business and consumer behavior (e.g., to invest in environmentally friendly energy production). The EU plan mimicks this two-step approach, though on a smaller scale. Our focus here is not the infrastructure part of these stimulus packages, but the macroeconomic stimulus part itself, and-particularly in the US - the financial-sector bailout measures that preceded it.

Most of the discussion surrounding the stimulus package has taken place at a very high level of aggregation. Despite the widely publicized failures of particular financial institutions, such as AIG, Lehman Brothers, Freddie Mac, and Fannie Mae, government officials spoke in terms of "the banking system," "the financial system," and the economy as a whole. Treasury Secretary Henry Paulson told Congress in September 2008 that radical steps were needed "to avoid a continuing series of financial institution failures and frozen credit markets that threaten American families' financial well-being, the viability of businesses both small and large, and the very health of our economy" (Paulson, 2008). The discussion of "frozen credit markets" focused on high-level indicators, with the focus on total lending, not the composition of lending among individuals, firms, and industries. The Federal Reserve System's actions, noted Chairman Ben Bernanke, were needed to "increase liquidity and stabilize markets" (Bernanke, 2008).

However, it seems clear that a decline in average home prices, reductions in total lending, and volatility in asset price indexes does not reveal much about the prices of particular homes, the cost of capital for specific borrowers, and the prices of individual assets. In analyzing the credit crisis, the critical question is which loans are not being made, to whom, and why? Indeed, it is impossible to understand the origins of the credit crisis without looking at the lending practices of government-sponsored enterprises like Freddie Mac and Fannie Mae and policies that encouraged lenders to lower underwriting standards, on the assumption that all borrowers were "really" equally credit-worthy (Liebowitz, 2009). The assumption of homogeneity-during a period of rapid central-bank credit expansion - is at the root of the financial crisis. 
In short, the critical issues here relate to the composition of lending, not the amount. Total lending, total liquidity, average equity prices, and the like obscure the key questions about how resources are being allocated across sectors, firms, and individuals, whether bad investments are being liquidated, and so on. Such aggregate notions homogenize — and in doing so, suppress critical information about relative prices. The main function of capital markets, after all, is not to moderate the total amount of financial capital, but to allocate capital across activities.

If not all borrowers are the same, it is even more true that not all banks are the same. And yet, the US Treasury's Troubled Assets Relief Program (TARP) was designed explicitly on the

premise that the banking system itself, rather than individual banks, was in trouble. To avoid signaling the financial conditions of specific banks to the market, the Treasury insisted that all large banks take TARP funds, whether they wanted to or not. Ultimately, some 250 banks refused to participate. Of course, such programs create a strong adverse-selection problem; banks that followed more prudent lending policies, did not invest in complex mortgage-backed securities, and the like have little incentive to take government subsidies accompanied by government control of future lending and investment (and even practices such as executive compensation). By bolstering inefficient banks and creating incentives to keep issuing mortgages that ought not to be issued, in the interests of reviving the macro-economy, policies such as TARP are repeating the mistakes that caused the problems in the first place.

\section{Heterogeneous Resources, Not Putty}

More generally, the US stimulus package, and similar proposals around the world, are characterized by Keynesian-style reliance on macroeconomic aggregates. According to the common wisdom, the bank crisis led to a collapse of effective aggregate demand, and only massive increases in government expenditure (and government debt) can kick-start the economy. However, in a world of heterogeneous capital resources, spending on some assets but not others alters the pattern of resource allocation, and, in a path-dependent process, the overall performance of the economy in the future. As F. A. Hayek, Keynes's most important intellectual oppo- 
nent, argued in the 1930s and 1940s, the economy's capital structure is a complex and delicate, one that cannot be mashed and pushed like putty (Hayek, 1941). Resources cannot be shifted costlessly from one activity to another, particularly in a modern economy in which much of those resources are embodied in industry-specific, firm-specific, and worker-specific capabilities. Even idle resources can be misallocated — what Hayek and his teacher Ludwig von Mises called "malinvestment"- if invested in activities that do not produce the goods and services the economy needs (Hayek, 1933).

Unfortunately, this perspective has mostly been lost in contemporary macroeconomic discussions. As Kenneth Boulding, reviewing Paul Samuelson's Foundations of Economic Analysis, wrote in 1948:

[I]t is a question of acute importance for economics as to why the macroeconomics predictions of the mathematical economists have been on the whole less successful than the hunches of the mathematically unwashed. The answer seems to be that when we write, for instance, 'let i, Y, and I stand, respectively, for the interest rate, income, and investment,' we stand committed to the assumption that the internal structures of these aggregates or averages are not important for the problem in hand. In fact, of course, they may be very important, and no amount of subsequent mathematical analysis of the variables can overcome the fatal defect of their heterogeneity.

History, rather than macro perspectives stressing homogeneity, may provide us with valuable lessons regarding the understanding of the micro-processes of entrepreneurship and economic recovery. A recent Kauffman Foundation report (Stangler, 2009) regarding the relationship between what they term "bureaucratic capitalism," financial downturns, and entrepreneurship in the United States over the last 100 years has important implications for potential solutions to the current financial crisis that relate to decentralized entrepreneurial activity. Specifically, the report documents periods when entrepreneurial entry was limited due to the unlevel playing field and concentration of economic power through government regulation that enabled large, sometimes inefficient, firms and powerful labor unions. Further, the report documents evidence that periods of economic downturns exhibit higher than average entrepreneurial activity, where decentralized decision making ensures that resources flow freely to their highest value uses, given 
heterogeneity in potential use and ownership of the relevant resources. Cole and Ohanian (2009) also argue that that the fruits of the 1930s - the most technologically progressive decade of the twentieth century (Field, 2003) — were delayed or reduced due to the New Deal-related policies that "suppress[ed] competition, and set prices and wages in many sectors well above their normal levels." These lessons indicate that the solutions to the current financial and economic crisis should leverage entrepreneurship and innovation that result from decentralized decision making, rather than assuming that all resources are homogenous putty that can be allocated centrally, or through government intervention and edict.

\section{The Case of Fiat-Chrysler}

One particular example where the standard macroeconomics assumptions of homogeneity and fungibility is likely to create problems is the US government's restructuring plans for the financial and automobile industries, and potentially for other sectors as well, including its proposals for sweeping changes in executive compensation, financial accounting, financial reporting, and more. Consider just one example — the link between Chrysler and Fiat.

Fiat, at the urging of the US government, completed an alliance with Chrysler in June 2009. The justifications for these actions are familiar to anyone who studies corporate strategythe mythological search for synergy (Larsson \& Finkelstein, 1999). Chrysler is supposed to get access to capital and to Fiat's knowledge of how to manufacture small cars profitably, and Fiat gets access to the US market through Chrysler's distribution network. Setting aside the observation that it is not at all clear that the proposed synergies could not be realized through some sort of market contract-what is the market failure that justifies more hierarchical forms of governance in this setting (Williamson, 1996)? - are the proposed synergies likely to be realized in a more integrated Fiat-Chrysler?

The data here are compelling. Most such corporate combinations-even those done voluntarily in non-crisis settings - fail to realize sought-for synergies. For example, Agarwal, Croson and Mahoney (2009) provide evidence of significant deviation between potential and rea- 
lized value creation in alliance settings, even when economic incentives are appropriately aligned. Information asymmetries, communication costs, cultural differences, managerial preferences, conflicts of interests - the reasons for failure are legion. If one had to bet on whether or not any such combination would yield anticipated synergies, the bet would have to be "no." How much less likely, then, will this "shotgun" marriage, arranged in times of crisis, generate the hoped-for benefits?

In the face of these very consistent results, why the policy of merging Chrysler and Fiat? One explanation - but certainly not the only explanation - is that macroeconomists who have been instrumental in developing this policy fail to recognize the heterogeneity and stickiness of the resources and capabilities of firms like Chrysler and Fiat. It appears the logic is: Chrysler needs small cars, Fiat has small cars, link them. Little problems like culture, language, employment relationships, history, the fact that a similar relationship between Chrysler and Daimler failed - none of these seems to play a large role in this story. But how can they, when economic policy is based on theories that assume away this very heterogeneity? ${ }^{2}$

Policy derived from strategic management and organization theory suggests a different approach. Even casual observation suggests that Chrysler still has some valuable resources and capabilities - the Jeep brand, some reasonably efficient manufacturing operations, some excellent dealerships, and so forth. Strategic management theory asks: How can these valuable resources and capabilities be reallocated to their most-valued uses? This suggests that many of Chrysler's resources and capabilities might be profitably sold to other firms and that such restructuring could benefit many of Chrysler's stakeholders, including its employees. Of course, this is the traditional role of bankruptcy protection - an opportunity for firms to restructure in a way that enables them to realize as much of their value as they can.

\footnotetext{
${ }^{2}$ Of course, private firms can also underestimate the implications of resource heterogeneity and stickiness in realizing cross-firm synergies (Roll, 1986). However, they face resource constraints and incentive schemes that limit aggressive expansion, and operate in a selection environment that punishes poor decisions ex post. Public agencies face different, and we would argue, substantially weaker, constraints in reallocating private resources.
} 
If the proposed synergies with Fiat do not materialize soon, strategic management theory suggests that yet another Chrysler bailout looms on the horizon. This theory also suggests that, just maybe, this is what the senior managers at Chrysler and Fiat are counting on. ${ }^{3}$

\section{Macroeconomic Policy with Heterogeneous Resources}

What, then, is the proper role of macroeconomic policy, and government intervention more generally, in a world of heterogeneous capital and human resources? What should governments do during an economic downturn? Is there a role for "activist" policy?

First, we think it is critically important to avoid public policies that generate malinvestment in the first place. As noted above, in our view the current crisis is not the result of unfettered markets (or, more colloquially, of "greed," or hubris, or regulators being "asleep at the wheel," or similar op-ed pronouncements), but the result of specific government policies designed to increase bank credit (particularly, but not exclusively, mortgage lending). The roots of the current crisis lie with the credit bubble that preceded it, and the best thing policymakers can do is not to create the next credit bubble. Given that the bubble has burst, however, the fastest way to economic recovery is to liquidate the bad investments as quickly as possible. When resources have been malinvested, the remedy is to redirect those resources to alternative, and higher-valued, uses. Of course, given asset specificity (Williamson, 1985), resources cannot be instantly and costlessly reallocated to alternative uses. However, contracting parties should be allowed to renegotiate resource use without artificial impediments to contract enforcement and resource mobility. Existing mechanisms for liquidating existing investments and organizations, such as bankruptcy, should be used where appropriate.

\footnotetext{
${ }^{3}$ In the 1970s-when Chrysler experienced its first financial crisis-Sidney Winter was asked to participate in a seminar series at the Yale School of Management tilted "What's Wrong with Chrysler?" With tongue firmly planted in cheek, Winter responded: "What's wrong with Chrysler? Rather, the question is, what is right with Chrysler, since their management team has cleverly positioned the firm to be re-capitalized with a government subsidized loan." When asked if he really thought that managers at Chrysler had purposely orchestrated this crisis, Winter paused, and then replied, "This time, probably not, but next time ..."-a particularly prescient prediction, even for Professor Winter.
} 
Obviously, this implies that bailouts — not only banks or industrial firms getting infusions of taxpayer funds to stave off bankruptcy, but delinquent mortgage borrowers being protected by law from foreclosure - do not lead to improvements in long-term economic performance. Rather, they perpetuate the inefficient allocation of resources that characterize the boom and bust. ${ }^{4}$ Indeed, the consensus among economic historians is that in the US New Deal policies of massive public works, wage and price controls, forced cartelization, high tariffs, and the like not only did not alleviate the Great Depression, but made what would have otherwise been a sharp, but shortlived, economic contraction into the worst depression in US history (Higgs, 1989; Vedder and Galloway, 1993; Cole and Ohanian, 2004, 2009; Stangler, 2009; Taylor, 2009). Moreover, the constantly changing mix of economic interventions generated a climate of what Higgs (1997) calls "regime uncertainty" that discouraged the private investment that would have stimulated economic recovery. It is vital that today's policymakers avoid the same mistakes. ${ }^{5}$

\section{CONCluding Discussion}

In summary, we feel strongly that the basic heterogeneity of individuals, firms, industries, and even regions cast serious doubt on the macroeconomic stimulus and stabilization policies currently pursued by Western governments. Of course, there are other reasons to question the dominant approach, which gives unprecedented authority to government agencies (e.g., the US Federal Reserve System's acquisition of trillions of dollars of off-balance-sheet obligations, with virtually no public accountability; the US government's huge equity stake in General Motors; a vast increase in most countries' public debt). These issues have made it into the public discourse. However, basic ideas from strategic management theory about the heterogeneity of resources, the role of entrepreneurs in experimenting with resource combinations, and the importance of the

\footnotetext{
${ }^{4}$ The appropriate role of public policy and private charity in alleviating financial hardships faced by individuals during periods of economic upheaval is, of course, a separate issue that we do not address here.

${ }^{5}$ Ironically, one of the sharpest critics of the Fed's expansionary policy during the 1920s and the Roosevelt Administration's interventions in the banking sector and the industrial economy is none other than Alan Greenspan (1966), who subsequently presided over a massive credit expansion in the 2000s and whose successor, Bernanke, led the government's interventions during the past year..
} 
market selection mechanism for testing among combinations have been completely absent from the public discourse. These issues, we have attempted to argue here, are fundamental in the creation (or destruction) of the appropriate institutions that underpin macroeconomic progress and social welfare.

Why is this? Why have management scholars been hesitant to enter the fray-not just now, when the crisis is at hand, but over many years, as management researchers and educators focused on relevance to business practitioners, while ignoring policymakers? In general, we have not attempted to claim a seat at the policy table, even though our core constituents-productive and resourceful entrepreneurs and business managers - strongly need us to do so.

Perhaps strategic management theory is too abstract, or too ad hoc, to be relevant to current affairs. Alternatively, some critics have pointed to the growing use of quantitative financial models not only for price forecasting, but also for valuing complex financial derivatives such as the mortgage-backed securities that filled the balance sheet of many struggling commercial banks, as a major cause of our financial problems ${ }^{6}$. Has strategic management theory, under the strong influence of economics, become so quantitative, impersonal, and mechanical, that it fails to train managers to exercise qualitative judgment about market conditions? ${ }^{7}$

\footnotetext{
${ }^{6}$ A recent Wired magazine cover story (Salmon, 2009) describes the obscure coplula function-more precisely, its use to estimate default correlation between credit risks-as "The Formula That Killed Wall Street." Harry Markowitz, the founder of modern portfolio theory, says he imagines a critic saying "You, Harry Markowitz, brought math into the investment process. . . It is fancy math that brought on this crisis. What makes you think now that you can solve it?" (Crovitz, 2008).

${ }^{7}$ Indeed, to the extent that strategic management theory has been invoked in context of the financial crisis, it usually has been to blame bad management theories for encouraging the practices that brought about the problem. Some commentators think that business schools' focus on shareholder wealth maximization, performance-based pay, and the virtue of self-interest have led banks, corporations, and governments astray (see Felin \& Foss [2009] for a critical discussion). "[B]usiness schools [promote] a particular brand of free-market ideology—squarely focused on shareholder maximization theories - that forms the staple fare of MBA and executive education courses today," claim Fisman and Khurana (2008). "It is the type of thinking ... that is now bringing capitalism to its knees." Notwithstanding that such comments ignore the fact that the United States has not been a free-market economy for more than a century, and that the blame can also be attributed to government policy effects in the mixed economy (Taylor, 2009), there is a clear need for public policy discussions to recognize the basic tenets of strategic management theory: heterogeneity matters, as do the incentives created by the institutional structure within which people makes decisions.
} 
Importantly, just as strategic management theory has much to offer to the understanding of the crisis and whether current policies represent useful remedies, the reverse also holds true: The crisis puts in stark perspective certain important weaknesses in current strategic management theory. Specifically, we argue in the following that strategic management theory needs to extend its focus on heterogeneous capabilities to include the capabilities of handling major, vaguely anticipated shocks.

\section{The Strategic Importance of "Deep" Uncertainty}

Adaptation to external change has long been a key theme in strategic management research. The influential notion of "dynamic capabilities" (Teece, Pisano, and Shuen, 1997) is fundamentally about differential abilities to adapt resource and capability configurations to changing external contingencies. However, neither dynamic capabilities theory, nor other strategic management perspectives focus on firms' adaptations to extreme events (McKelvey and Andriani 2005), or those major shocks that simultaneously affect multiple industries and economies, transforming the demand, input prices, relations to numerous stakeholders, political relations, etc.; implicitly, the external changes that strategic management theory highlights are incremental or transform single industries at a time, such as for example, demand shocks to one or a few markets (e.g. Christensen, 1997), changes in the technological or innovative environment facing a firm (e.g. Sarkar et al., 2006), problems with suppliers of key resources (Meyer, 1982), etc. Presumably because major shocks that impact the firm in all these dimensions are (luckily) rare incidents, strategic management scholars have not theorized how firms can successfully anticipate and react to them. The current crisis will hopefully place this subject high on the future research agenda of the field.

The current crisis also dramatically underscores the importance of cognitive phenomena treated under the rubrics of "genuine uncertainty" (Knight, 1921), "surprise" (Shackle, 1972) and "black swans" (Taleb, 2007), that is, decision situations where the problem isn't so much the inability to ascribe meaningful probabilities to outcomes but rather that the set of outcomes is not 
fully identified. While uncertainty has long been recognized as important to strategic management and organization theory, it has mainly been in the form of acknowledging the importance (necessity) of uncertainty to the existence of entrepreneurial rents (e.g., Rumelt, 1987). In contrast, very little of this theory has dealt with the decision-making implications of this kind of uncertainty. ${ }^{8}$

In contrast, economist Frank Knight (1921) placed uncertainty at the center of his theorizing. He argued that there is a specific cognitive faculty-which he called "judgment"- that is applied in those situations where there is no clear available decision rule. Knight was interested in the implications of judgment (i.e., profit); strategic management and organization theorists need to unpack judgment in terms of conceptualization and identification of antecedents in order to understand why and how - apart from sheer luck (Barney, 1986)-- some firms have handled the crisis better than other firms. Strategic management theory has insights to offer here.

Thus, the rich literature on top-management teams has, for example, explored the effects of top management heterogeneity on firms' competitive moves (e.g., Hambrick et al., 1996). This lens may be extended to examine the factors that explain why some top-management teams apparently demonstrate superior judgment and foresight. Another possible focus is offered by the literature dealing with firms' position in information networks. Position may influence the focal firm's ability to anticipate shocks as well as its access to resources that it may leverage in the context of responding to such shocks.

\section{The Importance of Political Strategy}

Another key lesson of the financial crisis is that firm performance depends, not only on resources and capabilities involved in production and market exchange, but also on the ability of managers to influence political decision makers. Entrepreneurs, in this climate, may need to be-

\footnotetext{
${ }^{8}$ Rigorous applications of real-options logic (e.g., Copeland and Antikarov, 2001) while emphasizing flexibility, assume risky decision making settings, not uncertain settings as defined by Knight (1921).
} 
come political or policy entrepreneurs, skilled at taking advantage, and influencing the direction, of the political process (Klein, McGahan, Mahoney, and Pitelis, 2009)

Of course, political strategy has always been part of a firm's overall strategic management. Rent-seeking behavior is as old as commerce itself, and firms in all parts of the world operate in heavily regulated environments. Within the field of strategic management, the literature on nonmarket strategy (de Figueiredo, 2009) highlights some of the ways firms attempt to influence their political and legal environments. However, the general field has tended to give political considerations relatively little attention, notwithstanding compelling calls for research incorporating political economy insights into strategic management (e.g. Henisz and Zellner, 2003). The financial crisis can be modeled as increasing the marginal returns to political strategy, relative to other strategic choices, which suggests that nonmarket strategy deserves to a play a stronger role in strategic management theory. Research that examines both the rents gained through non-market strategies, and the potential effects (positive or negative) of such strategies on total value creation will enable us to have a better understanding of the private and social benefits and costs of pursuing market vs. non market strategies. Moreover, work in resource based view and dynamic capabilities ought to be complemented with other lenses that examine not just the firm or industry as a unit of analysis, but also conceptualize firm strategy in the context of global industry-country-systems environments that become germane to effective policymaking. The policy implications of strategic management theory will be enhanced by examining firm strategic behavior using these different theoretical areas.

In summary, it is imperative that current policy deliberations be informed by a serious discourse and recognition of the micro underpinnings of macro-level phenomena. Strategic management scholars have much to offer, given our focus on the causes and consequences of heterogeneity of resources, particularly when coupled with entrepreneurial and decentralized decision making. It is also our responsibility to engage in meaningful and constructive conversations on how management theory can help resolve the current crisis - the future, both immediate and long term, is at stake. 


\section{REFERENCES}

Agarwal, R., D. Audretsch and M.B Sarkar, 2007. 'The Process of Creative Construction: Knowledge Spillovers, Entrepreneurship and Economic Growth.' Strategic Entrepreneurship Journal, 1(2): 263-86.

Agarwal, R., R. Croson and J. T. Mahoney. 2009 'Decision Making in Strategic Alliances: An Experimental Investigation.' Strategic Management Journal (forthcoming)

Barney, J. 1991. 'Firm Resources and Sustained Competitive Advantage.' Journal of Management 17: 99-120.

Black, J.A. and K.E. Boal. 1994. 'Strategic Resources: Traits, Configurations and Paths to Sustainable Competitive Advantage.' Strategic Management Journal 15: 131-48.

Bernanke, B. S. 2008. 'Testimony of Chairman Ben S. Bernanke Before the Committee on Banking, Housing, and Urban Affairs, US Senate.' Washington, DC: Board of Governors of the Federal Reserve System, September 23.

Boulding, K. E. 1948. 'Samuelson's Foundations: The Role of Mathematics in Economics,' Journal of Political Economy, 56: 187-199.

Bromiley, P., P. Navarro, and P. Sottile. 2008. 'Strategic Business Cycle Management and Organizational Performance: A Great Unexplored Research Stream.' Strategic Organization 6: 207-219.

Carlton, D. W. and J. M. Perloff. 2005. Modern Industrial Organization. Addison Wesley Publishers.

Commission of the European Communities. 2008. A European Economic Recovery Plan. Brussels.

Cole, H.L. and L.E. Ohanian. 2004. 'New Deal Policies and the Persistence of the Great Depression: a General Equilibrium Analysis.' Journal of Political Economy 112: 779-816.

Cole, H.L. and L.E. Ohanian. 2009. 'How Government Prolonged the Depression.' Wall Street Journal, February 2, 2009 
Copeland, T.E. and V. Antikarov. 2001. Real Options: A Practicioner's Guide. WW Norton \& Company.

Coy, P. 2009. 'What Good Are Economists Anyway?' Business Week, April 27, pp. $26-29$.

Crovitz, L. Gordon. 2008. 'The Father of Portfolio Theory on the Crisis: Harry Markowitz Says Valuation Is the Critical Step.' Wall Street Journal, November 3.

de Figueiredo, J. M. 2009. 'Integrated Political Strategy.' Advances in Strategic Management 26.

Dierickx, I., and K. Cool. 1989. 'Asset Stock Accumulation and Sustainability of Competitive Advantage.' Management Science 35: 1504-1511.

Elmendorf, D. 2009. 'The State of the Economy and Issues in Developing an Effective Policy Response.' Statement of the Director of the Congressional Budget Office before the Committee of the Budget, U.S. House of Representatives, January 29, 2009.

Felin, T. and N. J. Foss. 2005. 'Strategic Organization: A Field in Search of Micro-Foundations.' Strategic Organization 3: 441-455.

Felin, T. and N. J. Foss. 2009. 'Social Reality, the Boundaries of Self-Fulfilling Prophecy, and Economics.' Organization Science 20: 654-688.

Field, A. J. 2003. 'The Most Technologically Progressive Decade of the Century.' American Economic Review 93: 1399-1413.

Fisman, R. and R. Khurana. 2008. 'The Marie Antoinettes of Corporate America: How Business Schools Contributed to the Crisis.' Forbes, December 12.

Foss, N.J. 1994. 'The Biological Analogy and the Theory of the Firm: Marshall and Monopolistic Competition.' Journal of Economic Isssues 28: 1115-1136.

Fox, J. 2008. 'The Comeback Keynes.' Time, October 23.

Greenspan, A. 1966. 'Gold and Economic Freedom' in Rand, A. (ed.) 1986. Capitalism: The Unknown Ideal. New York: Signet Publishers.

Grossman, S. J., and O. D. Hart. 1986. 'The Costs and Benefits of Ownership: A Theory of Vertical and Lateral Integration.' Journal of Political Economy 94: 691-719. 
Hambrick, Donald C., Theresa Seung Cho, and Ming-Jer Chen 1996. 'The influence of top management team heterogeneity on firms' competitive moves,' Administrative Science Quarterly, 41: 659-684.

Hayek, F. A. von. 1933. Prices and Production. London: Routledge \& Kegan Paul.

Hayek, F. A. von. 1941. The Pure Theory of Capital. Chicago: University of Chicago Press.

Hayek, F. A. von. 1945. 'The Use of Knowledge in Society,' in Hayek, 1948. Individualism and Economic Order. Chicago: Chicago University Press.

Henisz, W. J., and B. A. Zelner. 2003. 'The Strategic Organization of Political Risks and Opportunities.' Strategic Organization 1: 451-460.

Higgs, R. 1989. Crisis and Leviathan: Critical Episodes in the Growth of American Government. New York: Oxford University Press.

Higgs, R. 1997. 'Regime uncertainty: why the Great Depression lasted so long and why prosperity resumed after the War.' Independent Review 1: 561-590.

Klein, P. G., A. M. McGahan, J. T. Mahoney, and C. Pitelis. 2009. 'Towards a Theory of Public Entrepreneurship.' Working Paper, Department of Business Administration, University of Illinois Urbana-Champaign.

Knight, Frank H. 1921. Risk, Uncertainty, and Profit. Chicago: Augustus M. Kelley.

Lachmann, Ludwig M. 1956. The Structure of Capital. Kansas City: Sheed Andrews and McNeel.

Larsson, R. and S. Finkelstein. 1999. 'Integrating Strategic, Organizational, and Human Resource Perspectives on Mergers and Acquisitions: A Case Survey of Synergy Realization.' Organization Science 10: 1-26.

Roll, R. 1986. 'The Hubris Hypothesis of Corporate Takeovers.' Journal of Business 59: 205216.

Liebowitz, S. J. 2009. 'Anatomy of a Train Wreck: Causes of the Mortgage Meltdown.' Forthcoming in Randall G. Holcombe and Benjamin Powell, eds., Housing America: Building Out of a Crisis. Oakland, Calif.: Independent Institute. 
Mankiw, G. N. 2002 Macroeconomics Worth Publishers, $5^{\text {th }}$ ed.

McKelvey, W., and Andriani, P. 2005. 'Why Gaussian Statistics Are Mostly Wrong for Strategic Organization.' Strategic Organization 3: 219-221.

Menger, C. 1871. Principles of Economics. New York: New York University Press.

Meyer, A. D. 1982. 'Adapting to Environmental Jolts.' Administrative Science Quarterly 27: 515-537.

Nelson, R. R. and S. G. Winter. 1982. An Evolutionary Theory of Economic Change. Cambridge, MA: The Belknap Press.

Oppers, S. E. 2002. 'The Austrian Theory of Business Cycles: Old Lessons for Modern Economic Policy?' IMF Working Paper No. 02/2.

Paulson, H. M. 2008. 'Testimony by Secretary Henry M. Paulson, Jr. before the Senate Banking Committee on Turmoil in US Credit Markets: Recent Actions regarding Government Sponsored Entities, Investment Banks and other Financial Institutions.' Washington, DC: United States Department of the Treasury, September 23.

Ricardo, D.. 1817. On the Principles of Political Economy and Taxation. London: John Murray.

Rumelt, R. P. 1987. 'Theory, Strategy, and Entrepreneurship.' In Teece, D. J., ed. 1987. The Competitive Challenge. San Francisco: Ballinger.

Salmon, F. 2009. 'Recipe for Disaster: The Formula That Killed Wall Street.' Wired, February 23.

Sarkar, MB, R. Echambadi, R. Agarwal, and B. Sen. 2006. 'The Effect of the Innovative Environment on the Exit of Entrepreneurial Firms.' Strategic Management Journal 27: 519-539.

Schumpeter, J. A. 1934. The Theory of Economic Development. Cambridge, MA: Harvard University Press.

Shackle, G. L.S. 1972. Epistemics and Economics. Cambridge: Cambridge University Press.

Stangler, D. 2009 The Economic Future Just Happened. Ewing Marion Kauffman Foundation Report, June 9, 2009 
Taleb, N. N.. 2007. The Black Swan: The Impact of the Highly Improbable. New York: Random House.

Taylor, J. B. 2009. How Government Created the Financial Crisis, Wall Street Journal, February 9

Teece, D. J. 2009. Dynamic Capabilities and Strategic Management: Organizing for Innovation and Growth. Oxford: Oxford University Press.

Teece, D. J., Pisano, G., and Shuen, A. 1997. 'Dynamic Capabilities and Strategic Management.' Strategic Management Journal 18: 509-534.

Van de Ven, A. 2007. Engaged Scholarship. Oxford: Oxford University Press.

Vedder, R. K., and Gallaway, L.E. 1993. Out of Work: Unemployment and Government in Twentieth-Century America. New York: Holmes and Meier.

Williamson, O. E. 1975. Markets and Hierarchies: Analysis and Antitrust Implications. New York: Free Press.

Williamson, O. E. 1985. The Economic Institutions of Governance. New York: Free Press.

Williamson, O. E. 1991. 'Comparative Economic Organization: The Analysis of Discrete Structural Alternatives.' Administrative Science Quarterly 36: 269-296.

Williamson, O. E. 1996. The Mechanisms of Governance. Oxford: Oxford University Press. 


\section{BIOSKETCHES}

Rajshree Agarwal is the John Georges Professor of Technology Management and Strategy at the University of Illinois, and the Director of the Innovation and Technology Management Initiatives in the College of Business. Her research interests focus on the implications of entrepreneurship and innovation for industry and firm evolution. Her recent projects examine strategic renewal of firms, the influence of dynamic knowledge-based capabilities on firm performance, and strategies that cause or inhibit knowledge transfer through employee entrepreneurship and mobility. Rajshree has published numerous articles in leading economics and management journals. She received her Ph.D. from the State University of New York at Buffalo.

Jay B. Barney is Chase Chair of Strategic Management at the Fisher College of Business at the Ohio State University. He received his Ph.D. from Yale University and holds honorary degrees from Lund University and the Copenhagen Business School. His research focuses on the causes and consequences of firm-specific and costly-to-copy resources and capabilities in the fields of strategic management and entrepreneurship.

Nicolai J. Foss is Professor of Strategy and Organization at the Copenhagen Business School (CBS) and the Norwegian School of Economics and Business Administration and Adjunct Professor at Agder and Lund Universities. Foss directs CBS's Center for Strategic Management and Globalization. His work has appeared in major management journals and he is the author of several books. His main research interests are the resource-based view, the theory of the firm, and social-science methodology. He received his Ph.D. from the Copenhagen Business School.

Peter G. Klein is Associate Professor in the Division of Applied Social Sciences at the University of Missouri, Adjunct Professor at the Norwegian School of Economics and Business Administration, and Associate Director of the Contracting and Organizations Research Institute. His work has appeared in leading management and economics journals and involves the relationship between entrepreneurship and economic organization, with applications to corporate diversification, innovation, financial institutions, and public policy. He received his Ph.D. from the University of California, Berkeley. He and Nicolai Foss co-founded the popular management blog Organizations and Markets. 


\section{SMG - Working Papers \\ www.cbs.dk/smg \\ 2003}

2003-1: Nicolai J. Foss, Kenneth Husted, Snejina Michailova, and Torben Pedersen: Governing Knowledge Processes: Theoretical Foundations and Research Opportunities.

2003-2: Yves Doz, Nicolai J. Foss, Stefanie Lenway, Marjorie Lyles, Silvia Massini, Thomas P. Murtha and Torben Pedersen: Future Frontiers in International Management Research: Innovation, Knowledge Creation, and Change in Multinational Companies.

2003-3: Snejina Michailova and Kate Hutchings: The Impact of In-Groups and OutGroups on Knowledge Sharing in Russia and China CKG Working Paper.

2003-4: Nicolai J. Foss and Torben Pedersen: The MNC as a Knowledge Structure: The Roles of Knowledge Sources and Organizational Instruments in MNC Knowledge Management CKG Working Paper.

2003-5: Kirsten Foss, Nicolai J. Foss and Xosé H. Vázquez-Vicente: “Tying the Manager's Hands": How Firms Can Make Credible Commitments That Make Opportunistic Managerial Intervention Less Likely CKG Working Paper.

2003-6: Marjorie Lyles, Torben Pedersen and Bent Petersen: Knowledge Gaps: The Case of Knowledge about Foreign Entry.

2003-7: Kirsten Foss and Nicolai J. Foss: The Limits to Designed Orders: Authority under "Distributed Knowledge" CKG Working Paper.

2003-8: Jens Gammelgaard and Torben Pedersen: Internal versus External Knowledge Sourcing of Subsidiaries - An Organizational Trade-Off.

2003-9: Kate Hutchings and Snejina Michailova: Facilitating Knowledge Sharing in Russian and Chinese Subsidiaries: The Importance of Groups and Personal Networks Accepted for publication in Journal of Knowledge Management.

2003-10: Volker Mahnke, Torben Pedersen and Markus Verzin: The Impact of Knowledge Management on MNC Subsidiary Performance: the Role of Absorptive Capacity CKG Working Paper.

2003-11: Tomas Hellström and Kenneth Husted: Mapping Knowledge and Intellectual Capital in Academic Environments: A Focus Group Study Accepted for publication in Journal of Intellectual Capital CKG Working Paper.

2003-12: Nicolai J Foss: Cognition and Motivation in the Theory of the Firm: Interaction or "Never the Twain Shall Meet"? Accepted for publication in Journal des Economistes et des Etudes Humaines CKG Working Paper.

2003-13: Dana Minbaeva and Snejina Michailova: Knowledge Transfer and Expatriation Practices in MNCs: The Role of Disseminative Capacity.

2003-14: Christian Vintergaard and Kenneth Husted: Enhancing Selective Capacity Through Venture Bases. 


\section{4}

2004-1: Nicolai J. Foss: Knowledge and Organization in the Theory of the Multinational Corporation: Some Foundational Issues

2004-2: Dana B. Minbaeva: HRM Practices and MNC Knowledge Transfer

2004-3: Bo Bernhard Nielsen and Snejina Michailova: Toward a Phase-Model of Global Knowledge Management Systems in Multinational Corporations

2004-4: Kirsten Foss \& Nicolai J Foss: The Next Step in the Evolution of the RBV: Integration with Transaction Cost Economics

2004-5: Teppo Felin \& Nicolai J. Foss: Methodological Individualism and the Organizational Capabilities Approach

2004-6: Jens Gammelgaard, Kenneth Husted, Snejina Michailova: Knowledge-sharing Behavior and Post-acquisition Integration Failure

2004-7: Jens Gammelgaard: Multinational Exploration of Acquired R\&D Activities

2004-8: Christoph Dörrenbächer \& Jens Gammelgaard: Subsidiary Upgrading? Strategic Inertia in the Development of German-owned Subsidiaries in Hungary

2004-9: Kirsten Foss \& Nicolai J. Foss: Resources and Transaction Costs: How the Economics of Property Rights Furthers the Resource-based View

2004-10: Jens Gammelgaard \& Thomas Ritter: The Knowledge Retrieval Matrix: Codification and Personification as Separate Strategies

2004-11: Nicolai J. Foss \& Peter G. Klein: Entrepreneurship and the Economic Theory of the Firm: Any Gains from Trade?

2004-12: Akshey Gupta \& Snejina Michailova: Knowledge Sharing in Knowledge-Intensive Firms: Opportunities and Limitations of Knowledge Codification

2004-13: Snejina Michailova \& Kate Hutchings: Knowledge Sharing and National Culture: A Comparison Between China and Russia

\section{5}

2005-1: Keld Laursen \& Ammon Salter: My Precious - The Role of Appropriability Strategies in Shaping Innovative Performance

2005-2: Nicolai J. Foss \& Peter G. Klein: The Theory of the Firm and Its Critics: A Stocktaking and Assessment

2005-3: Lars Bo Jeppesen \& Lars Frederiksen: Why Firm-Established User Communities Work for Innovation: The Personal Attributes of Innovative Users in the Case of Computer-Controlled Music

2005-4: Dana B. Minbaeva: Negative Impact of HRM Complementarity on Knowledge Transfer in MNCs

2005-5: Kirsten Foss, Nicolai J. Foss, Peter G. Klein \& Sandra K. Klein: Austrian Capital 
Theory and the Link Between Entrepreneurship and the Theory of the Firm

2005-1: Nicolai J. Foss: The Knowledge Governance Approach

2005-2: Torben J. Andersen: Capital Structure, Environmental Dynamism, Innovation Strategy, and Strategic Risk Management

2005-3: Torben J. Andersen: A Strategic Risk Management Framework for Multinational Enterprise

2005-4: Peter Holdt Christensen: Facilitating Knowledge Sharing: A Conceptual Framework

2005-5 Kirsten Foss \& Nicolai J. Foss: Hands Off! How Organizational Design Can Make Delegation Credible

2005-6 Marjorie A. Lyles, Torben Pedersen \& Bent Petersen: Closing the Knowledge Gap in Foreign Markets - A Learning Perspective

2005-7 Christian Geisler Asmussen, Torben Pedersen \& Bent Petersen: How do we Capture "Global Specialization" when Measuring Firms' Degree of internationalization?

2005-8 Kirsten Foss \& Nicolai J. Foss: Simon on Problem-Solving: Implications for New Organizational Forms

2005-9 Birgitte Grøgaard, Carmine Gioia \& Gabriel R.G. Benito: An Empirical Investigation of the Role of Industry Factors in the Internationalization Patterns of Firms

2005-10 Torben J. Andersen: The Performance and Risk Management Implications of Multinationality: An Industry Perspective

2005-11 Nicolai J. Foss: The Scientific Progress in Strategic Management: The case of the Resource-based view

2005-12 Koen H. Heimeriks: Alliance Capability as a Mediator Between Experience and Alliance Performance: An Empirical Investigation Into the Alliance Capability Development Process

2005-13 Koen H. Heimeriks, Geert Duysters \& Wim Vanhaverbeke: Developing Alliance Capabilities: An Empirical Study

2005-14 JC Spender: Management, Rational or Creative? A Knowledge-Based Discussion

\section{6}

2006-1: Nicolai J. Foss \& Peter G. Klein: The Emergence of the Modern Theory of the Firm

2006-2: Teppo Felin \& Nicolai J. Foss: Individuals and Organizations: Thoughts on a Micro-Foundations Project for Strategic Management and Organizational Analysis

2006-3: Volker Mahnke, Torben Pedersen \& Markus Venzin: Does Knowledge Sharing 
Pay? An MNC Subsidiary Perspective on Knowledge Outflows

2006-4: Torben Pedersen: Determining Factors of Subsidiary Development

2006-5 Ibuki Ishikawa: The Source of Competitive Advantage and Entrepreneurial Judgment in the RBV: Insights from the Austrian School Perspective

2006-6 Nicolai J. Foss \& Ibuki Ishikawa: Towards a Dynamic Resource-Based View: Insights from Austrian Capital and Entrepreneurship Theory

2006-7 Kirsten Foss \& Nicolai J. Foss: Entrepreneurship, Transaction Costs, and Resource Attributes

2006-8 Kirsten Foss, Nicolai J. Foss \& Peter G. Klein: Original and Derived Judgement: An Entrepreneurial Theory of Economic Organization

2006-9 Mia Reinholt: No More Polarization, Please! Towards a More Nuanced Perspective on Motivation in Organizations

2006-10 Angelika Lindstrand, Sara Melen \& Emilia Rovira: Turning social capital into business? A study of Swedish biotech firms' international expansion

2006-11 Christian Geisler Asmussen, Torben Pedersen \& Charles Dhanaraj: Evolution of Subsidiary Competences: Extending the Diamond Network Model

2006-12 John Holt, William R. Purcell, Sidney J. Gray \& Torben Pedersen: Decision Factors Influencing MNEs Regional Headquarters Location Selection Strategies

2006-13 Peter Maskell, Torben Pedersen, Bent Petersen \& Jens Dick-Nielsen: Learning Paths to Offshore Outsourcing - From Cost Reduction to Knowledge Seeking

2006-14 Christian Geisler Asmussen: Local, Regional or Global? Quantifying MNC Geographic Scope

2006-15 Christian Bjørnskov \& Nicolai J. Foss: Economic Freedom and Entrepreneurial Activity: Some Cross-Country Evidence

2006-16 Nicolai J. Foss \& Giampaolo Garzarelli: Institutions as Knowledge Capital: Ludwig M. Lachmann's Interpretative Institutionalism

2006-17 Koen H. Heimriks \& Jeffrey J. Reuer: How to Build Alliance Capabilities

2006-18 Nicolai J. Foss, Peter G. Klein, Yasemin Y. Kor \& Joseph T. Mahoney: Entrepreneurship, Subjectivism, and the Resource - Based View: Towards a New Synthesis

2006-19 Steven Globerman \& Bo B. Nielsen: Equity Versus Non-Equity International Strategic Alliances: The Role of Host Country Governance

\section{7}

2007-1 Peter Abell, Teppo Felin \& Nicolai J. Foss: Building Micro-Foundations for the Routines, Capabilities, and Performance Links 
2007-2 Michael W. Hansen, Torben Pedersen \& Bent Petersen: MNC Strategies and Linkage Effects in Developing Countries

2007-3 Niron Hashai, Christian G. Asmussen, Gabriel R.G. Benito \& Bent Petersen: Predicting the Diversity of Foreign Entry Modes

2007-4 Peter D. Ørberg Jensen \& Torben Pedersen: Whether and What to Offshore?

2007-5 Ram Mudambi \& Torben Pedersen: Agency Theory and Resource Dependency Theory: Complementary Explanations for Subsidiary Power in Multinational Corporations

2007-6 Nicolai J. Foss: Strategic Belief Management

2007-7 Nicolai J. Foss: Theory of Science Perspectives on Strategic Management Research: Debates and a Novel View

2007-8 Dana B. Minbaeva: HRM Practices and Knowledge Transfer in MNCs

2007-9 Nicolai J. Foss: Knowledge Governance in a Dynamic Global Context: The Center for Strategic Management and Globalization at the Copenhagen Business School

2007-10 Paola Gritti \& Nicolai J. Foss: Customer Satisfaction and Competencies: An Econometric Study of an Italian Bank

2007-11 Nicolai J. Foss \& Peter G. Klein: Organizational Governance

2007-12 Torben Juul Andersen \& Bo Bernhard Nielsen: The Effective Ambidextrous Organization: A Model of Integrative Strategy Making Processes.

\section{8}

2008-1 Kirsten Foss \& Nicolai J. Foss: Managerial Authority When Knowledge is Distributed: A Knowledge Governance Perspective

2008-2 Nicolai J. Foss: Human Capital and Transaction Cost Economics.

2008-3 Nicolai J. Foss \& Peter G. Klein: Entrepreneurship and Heterogeneous Capital.

2008-4 Nicolai J. Foss \& Peter G. Klein: The Need for an Entrepreneurial Theory of the Firm.

2008-5 Nicolai J. Foss \& Peter G. Klein: Entrepreneurship: From Opportunity Discovery to Judgment.

2008-6 Mie Harder: How do Rewards and Management Styles Influence the Motivation to Share Knowledge?

2008-7 Bent Petersen, Lawrence S. Welch \& Gabriel R.G. Benito: Managing the Internalisation Process - A Theoretical Perspective.

2008-8 Torben Juul Andersen: Multinational Performance and Risk Management Effects: Capital Structure Contingencies. 
2008-9 Bo Bernard Nielsen: Strategic Fit and the Role of Contractual and Procedural Governance in Alliances: A Dynamic Perspective.

2008-10 Line Gry Knudsen \& Bo Bernhard Nielsen: Collaborative Capability in R\&D Alliances: Exploring the Link between Organizational and Individual level Factors.

2008-11 Torben Juul Andersen \& Mahesh P. Joshi: Strategic Orientations of Internationalizing Firms: A Comparative Analysis of Firms Operating in Technology Intensive and Common Goods Industries.

2008-12 Dana Minbaeva: HRM Practices Affecting Extrinsic and Intrinsic Motivation of Knowledge Receivers and their Effect on Intra-MNC Knowledge Transfer.

2008-13 Steen E. Navrbjerg \& Dana Minbaeva: HRM and IR in Multinational Corporations: Uneasy Bedfellows?

2008-14 Kirsten Foss \& Nicolai J. Foss: Hayekian Knowledge Problems in Organizational Theory.

2008-15 Torben Juul Andersen: Multinational Performance Relationships and Industry Context.

2008-16 Larissa Rabbiosi: The Impact of Subsidiary Autonomy on MNE Knowledge Transfer: Resolving the Debate.

2008-17 Line Gry Knudsen \& Bo Bernhard Nielsen: Organizational and Individual Level Antecedents of Procedural Governance in Knowledge Sharing Alliances.

2008-18 Kirsten Foss \& Nicolai J. Foss: Understanding Opportunity Discovery and Sustainable Advantage: The Role of Transaction Costs and Property Rights.

2008-19 Teppo Felin \& Nicolai J. Foss: Social Reality, The Boundaries of Self-fulfilling Prophecy, and Economics.

2008-20 Yves Dos, Nicolai J. Foss \& José Santos: A Knowledge System Approach to the Multinational Company: Conceptual Grounding and Implications for Research

2008-21 Sabina Nielsen \& Bo Bernhard Nielsen: Why do Firms Employ foreigners on Their Top Management Teams? A Multi-Level Exploration of Individual and Firm Level Antecedents

2008-22 Nicolai J. Foss: Review of Anders Christian Hansen's “Uden for hovedstrømmen - Alternative strømninger i økonomisk teori"

2008-23 Nicolai J. Foss: Knowledge, Economic Organization, and Property Rights

2008-24 Sjoerd Beugelsdijk, Torben Pedersen \& Bent Petersen: Is There a Trend Towards Global Value Chain Specialization? - An Examination of Cross Border Sales of US Foreign Affiliates 
2008-25 Vikas Kumar, Torben Pedersen \& Alessandro Zattoni: The performance of business group firms during institutional transition: A longtitudinal study of Indian firms

2008-26 Sabina Nielsen \& Bo B. Nielsen: The effects of TMT and Board Nationality Diversity and Compensation on Firm Performance

2008-27 Bo B. Nielsen \& Sabina Nielsen: International Diversification Strategy and Firm Performance: A Multi-Level Analysis of Firm and Home Country Effects

\section{9}

2009-1 Nicolai J. Foss: Alternative Research Strategies in the Knowledge Movement: From Macro Bias to Micro-Foundations and Multi-Level Explanation

2009-2 Nicolai J. Foss \& Peter G. Klein: Entrepreneurial Alertness and Opportunity Discovery: Origins, Attributes, Critique

2009-3 Nicolai J. Foss \& Dana B. Minbaeva: Governing Knowledge: The Strategic Human Resource Management Dimension

2009-4 Nils Stieglitz \& Nicolai J. Foss: Opportunities and New Business Models: Transaction Cost and Property Rights Perspectives on Entrepreneurships

2009-5 Torben Pedersen: Vestas Wind Systems A/S: Exploiting Global R\&D Synergies

2009-6 Rajshree Agarwal, Jay B. Barney, Nicolai J. Foss \& Peter G. Klein: Heterogeneous Resources and the Financial Crisis: Implications of Strategic Management Theory 